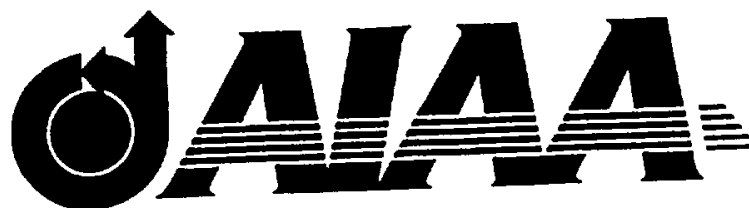

\section{AIAA 2001-0626}

Flame Chemiluminescence Rate

Constants for Quantitative Microgravity Combustion Diagnostics

Jorge Luque, Gregory P. Smith, Jay B. Jeffries, and David R. Crosley

SRI International

Menlo Park, CA

This is a preprint or reprint of a paper intended for presentation at a conference. Because changes may be made before formal publication, this is made available with the understanding that it will not be cited or reproduced without the permission of the author.

\section{9th AIAA Aerospace Sciences Meeting \& Exhibit 8-11 January 2001 / Reno, NV}


AIAA-2001-0626

\title{
FLAME CHEMILUMINESCENCE RATE CONSTANTS FOR QUANTITATIVE MICROGRAVITY COMBUSTION DIAGNOSTICS
}

\author{
Jorge Luque, ${ }^{*}$ Gregory P. Smith, Jay B. Jeffries, ${ }^{\dagger}$ David R. Crosley \\ Molecular Physics Laboratory, SRI International \\ Menlo Park CA 94025
}

\begin{abstract}
Absolute excited state concentrations of $\mathrm{OH}(\mathrm{A}), \mathrm{CH}(\mathrm{A})$, and $\mathrm{C}_{2}(\mathrm{~d})$ were determined in three low pressure premixed methane-air flames. Two dimensional images of chemiluminescence from these states were recorded by a filtered CCD camera, processed by Abel inversion, and calibrated against Rayleigh scattering. Using a previously validated 1-D flame model with known chemistry and excited state quenching rate constants, rate constants are extracted for the reactions $\mathrm{CH}+\mathrm{O}_{2} \rightarrow \mathrm{OH}(\mathrm{A})+\mathrm{CO}$ and $\mathrm{C}_{2} \mathrm{H}+\mathrm{O} \rightarrow \mathrm{CH}(\mathrm{A})+\mathrm{CO}$ at flame temperatures. Variations of flame emission intensities with stoichiometry agree well with model predictions.
\end{abstract}

\section{INTRODUCTION}

Optical emission signatures from combustion experiments provide a convenient chemically based diagnostic for a variety of applications. For example, microgravity experiments can be monitored without the instrumental complications of laser techniques. However, successful implementation of an emission diagnostic requires a model-based interpretation, and quantitative results depend on improved knowledge of the identity and rate constants for the reactions producing the excited electronic states observed.

We report here experiments in low pressure premixed flames to determine these rate constants for $\mathrm{CH}(\mathrm{A})$, $\mathrm{OH}(\mathrm{A})$, and $\mathrm{C}_{2}$ (d) production during methane combustion. A camera with appropriate optical filters records spatially resolved two-dimensional profiles of the emissions. An Abel inversion converts these images into flame-center height profiles. Rayleigh scattering from nitrogen is recorded with the same system to calibrate the measurements. Using a 1-D flame model which has been validated by flame radical measurements, previous LIF determinations of $\mathrm{CH}(\mathrm{A})$ and $\mathrm{OH}(\mathrm{A})$ quenching rate constants, and these results, we then derive rate constants for the reactions $\mathrm{CH}+\mathrm{O}_{2}$ $\rightarrow \mathrm{OH}(\mathrm{A})+\mathrm{CO}$ and $\mathrm{C}_{2} \mathrm{H}+\mathrm{O} \rightarrow \mathrm{CH}(\mathrm{A})+\mathrm{CO}$. Three 25-30 tor methane-air premixed flames of different stoichiometry are examined in this first work.

* Current address: LAM Research Corp. Fremont CA

${ }^{\dagger}$ Current address: Dept. of Mechanical Engineering, Stanford University, Stanford CA

Copyright 02001 by SRI International. Published by the American Institute of Aeronautics and Astronautics, Inc. with permission.
Modern laser diagnostics methods are typically used to provide species-specific, spatially-resolved measurements in combustion experiments, with the goal of providing some detailed data concerning the local progress of the flame chemistry, or the state of the fluid dynamics that has delivered a detected degree of combustion. ${ }^{1.2}$ PLIF images and local Raman measurements are examples. But because sophisticated optical and laser equipment, which are often in need of adjustment or repair, require high electrical power, and are quite massive to transport and accommodate, are required to conduct such measurements, simpler experimental diagnostics would find good use in microgravity and space-based flame experimentation. Optical flame emissions, like the familiar blue color of a gas stove, provide such an opportunity. This light is the result of specific molecular electronic transitions from excited states produced in non-equilibrium concentrations by specific chemical reactions. Thus the resulting chemiluminescence is a marker for this particular chemistry, and only simple optical detection equipment is required. These advantages were recognized early in the development of combustion science, and efforts were undertaken to characterize the spectroscopy and the reactions producing identified emissions. Gaydon provides an excellent summary of the emission spectra, flames, and possible reactions. ${ }^{3}$ For hydrocarbon-air flames, most light comes from $\mathrm{OH}(\mathrm{A}-\mathrm{X})$ at $280-310 \mathrm{~nm}, \mathrm{CH}(\mathrm{A}-\mathrm{X})$ at $430 \mathrm{~nm}, \mathrm{CH}(\mathrm{B}-$ $X)$ at $390 \mathrm{~nm}, C_{2}(d-a)$ Swan bands found mostly between $470-550 \mathrm{~nm}$, the $\mathrm{CO}_{2}$ flame band continuum between $320-500 \mathrm{~nm}$, and polynuclear aromatic molecules and soot luminescence in rich systems emitting in the visible. 
Little quantitative work on flame chemiluminescence has been published since Gaydon's review, but microgravity combustion experimental programs, ${ }^{4}$ and possible uses in combustion control applications ${ }^{5}$ have increased interest recently. As one example of a chemical correlation, Najm et $a^{6}{ }^{6}$ suggested the OH(A$\mathrm{X}$ ) ultraviolet emission measures the final stages of the $\mathrm{CH}_{x}$ reduction chain, for example. Walsh et al ${ }^{7.8}$ quantitatively measured the optical emission intensities from $\mathrm{CH}(\mathrm{A})$ at $431 \mathrm{~nm}$ and $\mathrm{OH}(\mathrm{A})$ at $308 \mathrm{~nm}$ in a methane jet diffusion flame, and modeled the results. Similar experiments are being undertaken for these flames in microgravity environments. ${ }^{4}$ In addition, they measured temperature and major species using Raman and Rayleigh scattering, and ground state $\mathrm{CH}, \mathrm{OH}$, and NO with laser induced fluorescence.

The reliability of the model comparison, and its validation for use on the flight experiments, depends largely on the availability of reliable kinetics for the production of the excited state species that emit. The loss rates through collisional quenching are largely well known from recent flow cell, flame, laser pyrolysis, and shock tube experiments and theoretical formulations. The current model of Walsh's data ${ }^{7.8}$ errs in predicting the results by factors of 2-6, so quantitative success and interpretation for these diagnostics depends on obtaining improved measurements of the $\mathrm{CH}(\mathrm{A})$ and $\mathrm{OH}(\mathrm{A})$ production reactions.

Studies of hydrocarbon flame chemiluminescence kinetics since Gaydon's book are limited, and vary in their recommendations. Flame studies are presented by Joklik et $\mathrm{al}^{10}$ and Grebe and Homann measure emission in a flow system." Shock tube measurements are presented by Hwang et al, ${ }^{12}$ and Mertens. ${ }^{13}$ The only direct rate measurements of reactions producing $\mathrm{CH}(\mathrm{A})$ are by Devriendt et al ${ }^{14}$ at room temperature. Among the older flame studies, suggested chemiluminescence rate constant values are given by Porter et al for $\mathrm{OH}$ and $\mathrm{CH}^{15}$ and by Bulewicz et al for $\mathrm{CH}^{16}$

Low pressure premixed laminar flames provide an ideal setting to determine these production rate constants. A series of flames investigated in our laboratory have been well characterized by temperature and absolute $\mathrm{OH}, \mathrm{CH}, \mathrm{NO}$, and $\mathrm{HCO}$ concentration distributions versus height above the burner surface, ${ }^{17}$ and our understanding of these flames and their chemistry validated by agreement with one-dimensional flame calculation results using the GRI-Mech 3.0 mechanism. ${ }^{18}$ Quenching rates for excited states were measured by LIF, ${ }^{9}$ and optical calibration techniques for absolute concentration determinations are operational. ${ }^{19}$ In the study reported here, we measure absolute emission intensities and excited state concentrations for $\mathrm{OH}(\mathrm{A}), \mathrm{CH}(\mathrm{A})$, and $\mathrm{C}_{2}(\mathrm{~d})$ in three low pressure methane-air flames of varying stoichiometry. Using modeling results, we will then provide suggested rate parameters for production reactions for the $\mathrm{OH}$ and $\mathrm{CH}$ chemiluminescence.

\section{EXPERIMENTAL}

The three premixed methane-air flames studied here are those labeled Standard ( $\phi=1.07,25$ torr), Lean $(\phi=0.81$, 25 torr), and Rich ( $\phi=1.28,30$ torr) in previous LIF studies of methane flame chemistry. ${ }^{17}$ Details, temperatures, and $\mathrm{CH}$ profiles versus height above the burner may be found there. ${ }^{17}$ Operation at low pressure allows good spatial resolution of the species, by which the progress of the flame chemistry can be followed. The flames are supported on a $6 \mathrm{~cm}$ diameter sintered plug McKenna burner, housed inside a vacuum chamber designed for optical probing. A concentric flow of argon is used to isolate and stabilize the flame. The burner translates vertically with respect to the optical axis of the laser and detection system. A servo control valve maintains the chamber and flame pressure, while mass flow controllers regulate the methane, oxygen, and nitrogen. A laser beam traverses the chamber through Brewster angle windows, with power monitored at the exit (Laser Precision Rj-7200), for the Rayleigh scattering calibration of the optical detection system. A large silica window, through which light may be imaged onto either the spectrometer or CCD camera detection systems, lies perpendicular to the laser path.

In order to compare experimental results for the excited state species concentrations and derive production rate constants, we performed one-dimensional flame model calculations using the Sandia code Premix ${ }^{20}$ and the GRI-Mech 3.0 chemical mechanism for methane oxidation. ${ }^{18}$ Measured flow rates and temperature profiles are also inputs. This follows the same procedure used for LIF measurements of ground state species in these flames. Reactions are added for the new excited state species $\mathrm{OH}(\mathrm{A})$ and $\mathrm{CH}(\mathrm{A})$ - radiative decay, collisional quenching, ${ }^{9}$ and potential production steps. In addition, a few reactions involving $\mathrm{C}$ and $\mathrm{C}_{2}$ species were added; since these species may be involved in the production kinetics, a more complete description is desirable. These addenda to GRI-Mech 3.0 are shown in Table 1 , where the ${ }^{*}$ signifies the 
excited state. The excited state production rates are provisional and will be discussed next.

The likely source of $\mathrm{OH}$ chemiluminescence cited by Gaydon $^{3}$ and others is the reaction $\mathrm{CH}+\mathrm{O}_{2}$. (Other energetically feasible reactions are $\mathrm{CH}_{2}$ or ${ }^{\prime} \mathrm{CH}_{2}+\mathrm{O}_{2}$. Several $\mathrm{HO}_{2}$ reactions and $\mathrm{O}+\mathrm{HCO}$ can be ruled out by the observation that $\mathrm{OH}(\mathrm{A})$ is found at higher flame temperatures.) Porter et al $^{15}$ measured species and emissions in several 18 torr methane and acetylene flames, and using appropriate transition strengths and estimated quenching rates deduced the rate constant adopted for our mechanism. In hydrogen flames and in burnt gas regions, the recombination or inverse predissociation reaction $\mathrm{O}+\mathrm{H}+\mathrm{M}$ is responsible for $\mathrm{OH}(\mathrm{A})$ formation. Both Kaskan and Davis et al. ${ }^{22}$ have derived rate constants from hydrogen flame data, assuming the reaction to be $\mathrm{H}+2 \mathrm{OH} \rightarrow \mathrm{OH}(\mathrm{A})+\mathrm{H}_{2} \mathrm{O}$ (a recombination assisted excitation). A reanalysis of some of their data in terms of an $\mathrm{O}+\mathrm{H}+\mathrm{M}$ reaction, using current quenching rates, ${ }^{9}$ provides the tabulated rate constant, with an uncertainty of at least $60 \%$. Experiments with our low pressure hydrogen flames ${ }^{25}$ could refine this value in the future.

The reaction responsible for $\mathrm{CH}$ chemiluminescence, the A-X at $430 \mathrm{~nm}$ and B-X at $390 \mathrm{~nm}$, is less certain. Three reactions have been proposed, and literature analysis of experiments often conflict or omit the other possible steps. For the reaction $\mathrm{C}_{2} \mathrm{H}+\mathrm{O}_{2}$, we made an Arrhenius fit to the room temperature rate constant of Devriendt et al. ${ }^{14}$ and the shock tube emission results at 2000-2600K from Hwang et al. ${ }^{12}$ This is 4 times higher than Merten's recent $3000 \mathrm{~K}$ shock tube results, ${ }^{13}$ which would suggest a higher activation energy and as much as a 16 -fold reduction at $1500 \mathrm{~K}$ flame temperatures. For the reaction $\mathrm{C}_{2} \mathrm{H}+\mathrm{O}$, at room temperature, Devriendt et al..$^{14}$ measure $1.1 \times 10^{13} \mathrm{~cm}^{3} \mathrm{~mole}^{-1} \mathrm{~s}^{-1}$ but Grebe and Homann" propose a much lower value (dependent on their uncertain production kinetics for $\mathrm{C}_{2} \mathrm{H}$ ) from their flow reactor data, $7.0 \times 10^{\prime \prime}$. Joklik et $\mathrm{al}^{10}$ estimate a value of $7.0 \times 10^{12}$ from their low pressure acetylene flame study. An average value of $6.2 \times 10^{12}$ is used in the preliminary mechanism, with no temperature dependence assumed and large error limits likely at flame temperatures. Finally, the step $\mathrm{C}_{2}$ $+\mathrm{OH}$ is favored as the source of the excited $\mathrm{CH}$ observed in flames by Bulewicz et al. ${ }^{16}$ and Porter et al. ${ }^{15}$ The mechanism rate constant is from a reanalysis of Porter's results using a shorter revised $C_{2}(d)$ radiative lifetime ${ }^{26}$ and our quenching rates for $\mathrm{CH}(\mathrm{A})$, 9 and is about twice the estimated value given by Bulewicz. ${ }^{16}$
Modeling work on the source reaction rates for $C_{2}(d-a)$ emission must wait for measurements on the quenching loss rates, using LIF. Appearance of these emissions in rich flames or regions suggests to many that possible $O$ atom reactions are not likely to be responsible. The isotope work of Ferguson ${ }^{27}$ has shown that reactions

Table 1. Chemiluminescence Kinetics Additions $\mathrm{k}=\mathrm{AT} \exp (-\mathrm{E} / \mathrm{RT}) \quad \mathrm{A}\left(\mathrm{cm}^{3}\right.$, mole, $\left.\mathrm{s}\right) \mathrm{E}(\mathrm{kcal} / \mathrm{mole})$

\begin{tabular}{|c|c|c|c|c|}
\hline Reaction & A & In & E & Source \\
\hline $\mathrm{C} 2+\mathrm{H} 2=\mathrm{C} 2 \mathrm{H}+\mathrm{H}$ & $4.00 \mathrm{e} 5$ & 2.4 & 1000 & $\begin{array}{l}\text { est. } \\
(\mathrm{C} 2 \mathrm{H}+\mathrm{H} 2)\end{array}$ \\
\hline $\mathrm{CH}+\mathrm{CH}=\mathrm{C} 2+\mathrm{H} 2$ & $5.00 \mathrm{e} 12$ & 0 & 0 & est. \\
\hline $\mathrm{C}+\mathrm{C}+\mathrm{M}=\mathrm{C} 2+\mathrm{M}$ & $3.00 \mathrm{e} 14$ & to & -1000 & est. $(2 \mathrm{X}+\mathrm{M})$ \\
\hline $\mathrm{C}+\mathrm{CH}=\mathrm{C} 2+\mathrm{H}$ & $5.00 \mathrm{e} 13$ & to & 0 & est. $(\mathrm{O}+\mathrm{CH})$ \\
\hline $\mathrm{O}+\mathrm{C} 2=\mathrm{C}+\mathrm{CO}$ & $5.00 \mathrm{e} 13$ & 0 & 0 & est. $(\mathrm{O}+\mathrm{CH})$ \\
\hline $\mathrm{C} 2+\mathrm{O} 2=\mathrm{CO}+\mathrm{CO}$ & $9.00 \mathrm{e} 12$ & to & 980 & ref. 21 \\
\hline $\mathrm{CH}+\mathrm{O} 2=\mathrm{CO}+\mathrm{OH}^{*}$ & $6.00 \mathrm{e} 10$ & 0 & 0 & ref. 15 \\
\hline $\mathrm{C} 2+\mathrm{OH}=\mathrm{CO}+\mathrm{CH}^{*}$ & $1.11 \mathrm{e} 13$ & p & 0 & $\begin{array}{l}\text { ref. } 15 \\
\text { reanalyzed }\end{array}$ \\
\hline $\mathrm{C} 2 \mathrm{H}+\mathrm{O}=\mathrm{CO}+\mathrm{CH}^{*}$ & $6.20 \mathrm{e} 12$ & 0 & 0 & ref. $10,11,14$ \\
\hline $\mathrm{C} 2 \mathrm{H}+\mathrm{O} 2=\mathrm{CO} 2+\mathrm{CH}^{*}$ & $4.10 \mathrm{e} 13$ & to & 4500 & ref. 12,14 \\
\hline $\mathrm{O}+\mathrm{H}+\mathrm{M}=\mathrm{OH}^{*}+\mathrm{M}$ & $3.63 \mathrm{e} 13$ & 10 & 0 & $\begin{array}{l}\text { ref. } 22 \\
\text { reanalyzed }\end{array}$ \\
\hline $\mathrm{C}+\mathrm{H}+\mathrm{M}=\mathrm{CH}^{*}+\mathrm{M}$ & $3.63 \mathrm{e} 13$ & 0 & 0 & $\begin{array}{l}\text { est. } \\
(\mathrm{O}+\mathrm{H}+\mathrm{M})\end{array}$ \\
\hline $\mathrm{CH}^{*} \rightarrow \mathrm{CH}$ & $1.86 \mathrm{e} 6$ & 0 & 0 & ref. 23 \\
\hline $\mathrm{CH}^{*}+\mathrm{N} 2=\mathrm{CH}+\mathrm{N} 2$ & 303 & 3.4 & -381 & ref. 9 \\
\hline $\mathrm{CH}^{*}+\mathrm{O} 2=\mathrm{CH}+\mathrm{O} 2$ & $2.48 \mathrm{e} 6$ & 2.14 & -1720 & 0 ref. 9 \\
\hline $\mathrm{CH}^{*}+\mathrm{H} 2 \mathrm{O}=\mathrm{CH}+\mathrm{H} 2 \mathrm{O}$ & $5.30 \mathrm{e} 13$ & 0 & 0 & ref. 9 \\
\hline $\mathrm{CH}^{*}+\mathrm{H} 2=\mathrm{CH}+\mathrm{H} 2$ & $1.47 \mathrm{e} 14$ & 0 & 1361 & ref. 9 \\
\hline $\mathrm{CH}^{*}+\mathrm{CO} 2=\mathrm{CH}+\mathrm{CO} 2$ & 0.241 & 4.3 & -1694 & 4 ref. 9 \\
\hline $\mathrm{CH}^{*}+\mathrm{CO}=\mathrm{CH}+\mathrm{CO}$ & $2.44 \mathrm{e} 12$ & 0.5 & 0 & ref. 9 \\
\hline $\mathrm{CH}^{*}+\mathrm{CH} 4=\mathrm{CH}+\mathrm{CH} 4$ & $1.73 \mathrm{e} 13$ & 0 & 167 & ref. 9 \\
\hline $\mathrm{OH}^{*} \rightarrow \mathrm{OH}$ & $1.45 \mathrm{e} 6$ & 0 & 0 & ref. 24 \\
\hline $\mathrm{OH}^{*}+\mathrm{N} 2=\mathrm{OH}+\mathrm{N} 2$ & $1.08 \mathrm{e} 11$ & 0.5 & -1238 & 8 ref. 9 \\
\hline $\mathrm{OH}^{*}+\mathrm{O} 2=\mathrm{OH}+\mathrm{O} 2$ & $2.10 \mathrm{e} 12$ & 0.5 & -482 & ref. 9 \\
\hline $\mathrm{OH}^{*}+\mathrm{H} 2 \mathrm{O}=\mathrm{OH}+\mathrm{H} 2 \mathrm{O}$ & $55.92 \mathrm{e} 12$ & 0.5 & -861 & ref. 9 \\
\hline $\mathrm{OH}^{*}+\mathrm{H} 2=\mathrm{OH}+\mathrm{H} 2$ & $2.95 \mathrm{e} 12$ & 0.5 & -444 & ref. 9 \\
\hline $\mathrm{OH}^{*}+\mathrm{CO} 2=\mathrm{OH}+\mathrm{CO} 2$ & $22.75 \mathrm{e} 12$ & 0.5 & -968 & ref. 9 \\
\hline $\mathrm{OH}^{*}+\mathrm{CO}=\mathrm{OH}+\mathrm{CO}$ & $3.23 \mathrm{e} 12$ & 0.5 & -787 & ref. 9 \\
\hline $\mathrm{OH}^{*}+\mathrm{CH} 4=\mathrm{OH}+\mathrm{CH} 4$ & $43.36 \mathrm{e} 12$ & 0.5 & -635 & ref. 9 \\
\hline
\end{tabular}

of two separate single-carbon-atom species are responsible. Candidates include $\mathrm{C}+\mathrm{CH}, \mathrm{CH}+\mathrm{CH}$, and $\mathrm{C}+\mathrm{CH}_{2}$. It will be very hard to distinguish these experimentally, and may not matter operationally. Emission and LIF measurements in hydrogen arcjets seeded with methane may provide additional useful data. $^{28}$

Low resolution sample spectra from the center region of maximum luminescence were recorded in the three 
flames, using a $1.05 \mathrm{~m}$ focal length (f/4.5) ultraviolet camera lens to image the light onto the fiber optic entrance channel of a spectrum analyzer (SC Technology Process Sentry 400, resolution $3.2 \mathrm{~nm}$ ). The results are shown in Figure 1, after correcting for detector wavelength response. The main features are clearly identifiable as $\mathrm{OH}(\mathrm{A}-\mathrm{X}), \mathrm{CH}(\mathrm{B}-\mathrm{X}), \mathrm{CH}(\mathrm{A}-\mathrm{X})$, and $\mathrm{C}_{2}(\mathrm{~d}-\mathrm{a})$ bands. The $\mathrm{CH}$ and especially $\mathrm{C}_{2}$ emissions are very dependent on stoichiometry, and the $C_{2}$ Swan bands cannot be identified in the lean flame spectrum (see the 10x insert). Some underlying emission, particularly near $350 \mathrm{~nm}$ and to the red of $430 \mathrm{~nm}$, especially for the lean flame, may be due to the $\mathrm{CO}_{2}{ }^{*}$ continuum. But it is too faint for worthwhile analysis. In the following analysis, we assume light from 280 $340 \mathrm{~nm}$ is from OH(A-X), that between $380 \mathrm{~nm}$ and $450 \mathrm{~nm}$ is excited $\mathrm{CH}$, and beyond $450 \mathrm{~nm}$ for the standard and rich flames only is the $\mathrm{C}_{2}$ Swan bands. Note the $\Delta v=+2 S$ wan bands will contribute to the intensity assigned to $\mathrm{CH}(\mathrm{A}-\mathrm{X})$ near $430 \mathrm{~nm}$, but little error is introduced - the contribution is probably less than $10 \%$ of the $\Delta v=+1$ peak at $470 \mathrm{~nm}^{29}$

A set of 2-D flame emission images were recorded through the same camera lens from $1 \mathrm{~m}$ (camera $\mathrm{f} / 5.6$ ) to obtain line-of-sight integrated luminescence signals for the three emitters and three flames. Signal was detected with a gated intensified CCD camera operating in simple shutter mode(Princeton Instruments, ICCD 576G.RBT, 14 bits dynamic range, $384 \times 576$ pixels). Imaging an illuminated piece of graph paper established the pixel size to be $0.0135 \mathrm{~cm}$ at the flame, and identified the burner center and surface in the images. Five filters were used in front of the camera: a Schott GG455 glass long wave pass (LWP) filter for the Swan bands; a Schott GG375 LWP filter which will transmit $\mathrm{CH}$ as well as $\mathrm{C}_{2}$ emissions; alternatively, a narrow band $430 \pm 10 \mathrm{~nm}$ interference filter for $\mathrm{CH}(\mathrm{A}-\mathrm{X})$; a narrow band $300 \pm 10 \mathrm{~nm}$ interference filter passing some of the $\mathrm{OH}(\mathrm{A}-\mathrm{X})$ light; and a UG-11 Schott glass filter which transmits light readily from $275-370 \mathrm{~nm}$ to view all the $\mathrm{OH}(\mathrm{A}-\mathrm{X})$. The difference image between the GG375 and GG455 filters covers the $370-460 \mathrm{~nm}$ window to isolate the $\mathrm{CH}$ emissions. Filter transmission curves were generated from spectra taken using the Process Sentry 400 spectrum analyzer and the outer cone excited $\mathrm{OH}$ and $\mathrm{CO}_{2}$ uv-blue light from a Bunsen flame. The $\mathrm{OH}$ emission feature in this flame lets one determine the fraction of $\mathrm{OH}(\mathrm{A}-\mathrm{X})$ radiation transmitted by the narrow band filter. The intensifier gain was calibrated from repeat measurements with different settings, and the manufacturers' wavelength dependence was assumed. This contributes about a factor of 3 difference when relating emitting $\mathrm{OH}$ to $\mathrm{CH}$, and adds uncertainty to the $\mathrm{OH}(\mathrm{A})$ determination. (The optical system was calibrated at $434 \mathrm{~nm}$.) Finally, in addition to these gain and transmission terms, the recorded emission intensities must be multiplied by the ratio of observation time to radiative lifetime in order to obtain excited state concentrations. If we have the same amounts of steady state $\mathrm{OH}(\mathrm{A})$ and $\mathrm{CH}(\mathrm{A})$ in a flame, we will see more $\mathrm{CH}$ emission because its radiative rate is faster.

The images measure integrated emissivities through the depth dimension of the cylindrical flames, but comparison to 1-D chemical models requires localized excited state concentrations near the uniform center of the flame, as a function of height above the burner. An Abel inversion of the data must be performed, and we used the code of Walsh et al. ${ }^{7}$ based on work by Dasch. ${ }^{30}$ Binning of data pixels and operation at lower spatial resolution is necessary to avoid excessive noise in the inverted result. The current analysis added 16 horizontal and 2 vertical pixels, and used 3 point smoothing, yielding a resolution of $0.05 \mathrm{~cm}$ height and $0.43 \mathrm{~cm}$ radial. After inversion, the results provide emission intensities for each species and flame from specific local volume elements.

To relate the point emission intensities of the Abel inverted images to excited state concentrations, the system optical detection efficiency must be calibrated. The same Rayleigh scattering method previously employed to determine absolute ground state concentrations from flame LIF measurements ${ }^{19}$ was used. The CCD camera system with GG-375 filter is operated with a $50 \mathrm{~ns}$ gate triggered by the firing of an excimer pumped dye laser tuned to $434 \mathrm{~nm}$. The laser beam is directed through the chamber above the burner, filled at 50-100 torr nitrogen, and the power (20 $\mu \mathrm{J} /$ pulse at $10 \mathrm{~Hz}$ ) is measured(Laser Precision Rj-4200 meter). About 600 shots are averaged, and then the process is repeated with the nitrogen and laser beam replaced by the standard flame and the $\mathrm{CH}$ and $\mathrm{C}_{2}$ luminescence. The Rayleigh signal is integrated over a $2.16 \mathrm{~cm}$ (160 pixel) length and the full 6 pixel heightwidth of the laser beam.

The information is available to compute the number of Rayleigh excitations in the observation volume, $N^{*}(R)$, relate it to the observed signal intensity, and use this ratio to determine the $\mathrm{CH}(\mathrm{A})$ concentration from the intensity of $\mathrm{CH}(\mathrm{A}-\mathrm{X})$ signal.

$$
N^{*}(R)=4 \pi \sigma \rho d I(R),
$$


where $\sigma=2.4 \times 10^{-27} \mathrm{~cm}^{2}$ is the $N_{2}$ Rayleigh crosssection at $434 \mathrm{~nm},{ }^{\prime} \mathrm{d}=2.16 \mathrm{~cm}, \rho$ at 100 torr is $2.17 \mathrm{x}$ $10^{18} \mathrm{~cm}^{-3}$, and $\mathrm{I}(\mathrm{R})=4.3 \times 10^{13}$ photons/pulse. (The camera is perpendicular to the laser, which is polarized in the plane of the optical system.) Then the excited state concentration

$$
\begin{aligned}
{\left[\mathrm{CH}^{*}\right] } & =\mathrm{N}\left(\mathrm{CH}^{*}\right) / \mathrm{V}(\text { Abel }) \\
& =\mathrm{N}^{*}(\mathrm{R}) \times \mathrm{S}(\text { Abel }) / \mathrm{S}(\mathrm{R}) \times \mathrm{t}(\mathrm{rad}) /(\mathrm{obs})
\end{aligned}
$$

where the ratio of radiative lifetime to observation gate $\mathrm{t}(\mathrm{rad}) / \mathrm{t}(\mathrm{obs})=537 \mathrm{~ns} / 50 \mathrm{~ns}, \mathrm{~S}$ are the respective signal levels, $\mathrm{V}$ (Abel) is the volume of the Abel inverted cell, $\mathrm{N}\left(\mathrm{CH}^{*}\right)$ is the number of excited state $\mathrm{CH}$ molecules in the cell, and $N^{*}(R)$ is from (1).

\section{RESULTS}

Figure 2 displays the image of the $\mathrm{OH}(310 \mathrm{~nm})$ light emission from the standard 25 torr $\Phi=1.07$ methane-air flame. The resulting Abel inversion is shown below the image. Results for the $\mathrm{CH}(370-460 \mathrm{~nm})$ and $\mathrm{C}_{2}(\lambda>460$ $\mathrm{nm}$ ) emissions are very similar. A flattening of the profiles can be seen, as might be expected from the inversion and the general saucer shape of species distributions in these flames. ${ }^{31}$ Vertical cuts through these figures to compare height distributions show that the inversion has minor effects on most excited state peak positions, widths, and amounts. If one assumes, for example, that the excited $\mathrm{CH}$ is uniformly distributed over the nominal $6 \mathrm{~cm}$ burner diameter instead of taking the radial data and performing the inversion, only a $5 \%$ error is introduced:

Traces of an uneven pattern are apparent in some of the Abel results. The halves are slightly asymmetric, the central region $2-4$ cells often have $10-15 \%$ lower concentrations than the peak found toward mid-radius of the flame, and sometimes the central region is abruptly shifted toward the burner surface. For $\mathrm{OH}^{*}$, optical depth calculations suggest that absorption of emission from the flame center by $\mathrm{OH}(\mathrm{X})$ may contribute to this pattern. Future analysis refinements may reduce this $-10 \%$ uncertainty from the inversion.

The results for the maximum excited state concentrations and ratios between flames are given in Table 2, along with comparisons to the starting model results. The reaction $\mathrm{C}_{2} \mathrm{H}+\mathrm{O}_{2}$ dominates model $\mathrm{CH}^{*}$ production and this model greatly overpredicts the experimental results. A second model result without this step is given in the penultimate column, and gives better predictions. The temperatures at the chemiluminescence peaks range from 1500-1950K; at
$1700 \mathrm{~K}$ and 25 torr, a concentration of $10^{7} \mathrm{~cm}^{-3}$ corresponds to 70 parts per trillion. We estimate uncertainties of $20 \%$ in relative values, and $35 \%$ in absolute concentrations. The $\mathrm{CH}(\mathrm{A})$ interference filter results are consistent with the values obtained from the difference image of the glass filters shown in Table 2. The $\mathrm{CH}(\mathrm{A}) / \mathrm{CH}^{*}$ ratios show $80 \%$ of the emission coming from the A state ( 0.8 for the standard and rich flames, 0.6 for the lean one), which roughly agrees with the Fig. 1 spectra.

\begin{tabular}{|c|c|c|c|c|c|}
\hline \multirow{2}{*}{ Species } & \multicolumn{5}{|c|}{$\left(e 8=\times 10^{8}\right)$} \\
\hline & Flame(s) & Exper. & Model & $\begin{array}{c}w / 0 \\
\mathrm{C} 2 \mathrm{H}+\mathrm{O} 2\end{array}$ & $\begin{array}{l}\text { Exper.I } \\
\text { Model }\end{array}$ \\
\hline $\mathrm{OH}^{*}$ & Rich & $2.33 \mathrm{e} 8$ & $9.03 \mathrm{e} 7$ & & 2.58 \\
\hline $\mathrm{OH}^{*}$ & Standard & $1.56 \mathrm{e} 8$ & $5.38 \mathrm{e} 7$ & & 2.90 \\
\hline $\mathrm{OH}^{*}$ & Lean & $1.20 \mathrm{e} 8$ & $3.79 \mathrm{e} 7$ & & 3.17 \\
\hline $\mathrm{CH}^{*}$ & Rich & $5.57 \mathrm{e} 7$ & $2.11 \mathrm{e} 9$ & $4.41 \mathrm{e} 7$ & $026,1.26$ \\
\hline $\mathrm{CH}^{*}$ & Standard & $9.62 \mathrm{e} 6$ & $3.09 \mathrm{e} 8$ & $9.93 \mathrm{e} 6$ & $.031,0.97$ \\
\hline $\mathrm{CH}^{*}$ & Lean & $2.36 \mathrm{e} 6$ & $4.66 \mathrm{e} 7$ & $1.62 \mathrm{e} 6$ & $051,1.46$ \\
\hline $\mathrm{C}^{*}$ * & Rich & $1.06 \mathrm{e} 7$ & & & \\
\hline $\mathrm{C} 2^{*}$ & Standard & $1.26 \mathrm{e} 6$ & & & \\
\hline $\mathrm{OH}^{*}$ & $\begin{array}{l}\text { Rich/ } \\
\text { Standard }\end{array}$ & 1.49 & 1.68 & & \\
\hline $\mathrm{OH}^{*}$ & $\begin{array}{l}\text { Lean/ } \\
\text { Standard }\end{array}$ & 0.77 & 0.70 & & \\
\hline $\mathrm{CH}^{*}$ & $\begin{array}{l}\text { Rich/ } \\
\text { Standard }\end{array}$ & 5.8 & 6.8 & 4.4 & \\
\hline $\mathrm{CH}^{*}$ & $\begin{array}{l}\text { Lean/ } \\
\text { Standard }\end{array}$ & $\begin{array}{c}0.24 \\
(.17 \mathrm{~A})\end{array}$ & 0.15 & 0.16 & \\
\hline
\end{tabular}

Table 2. Maximum Excited State Concentrations $\left(\mathrm{cm}^{-3}\right)$

The flame ratios of excited state concentrations are fairly well reproduced by the model results. This agreement supports the chosen chemistry and affirms the ability to predict the stoichiometry dependence of the emissions. The lean $\mathrm{CH}$ ratio is high for the 370$460 \mathrm{~nm}$ glass filter result, but matches predictions for the narrow band $\mathrm{CH}(\mathrm{A}-\mathrm{X})$ value, suggesting that some non- $\mathrm{CH}$ background may contribute (see also the Fig. 1 spectrum). The rich $\mathrm{CH}^{*}$ ratio lies between the values from models dominated by $\mathrm{C}_{2} \mathrm{H}+\mathrm{O}_{2}$ and $\mathrm{C}_{2} \mathrm{H}+\mathrm{O}$, which suggests both reactions may contribute. With respect to absolute concentrations, the model underpredicts $\mathrm{OH}(\mathrm{A})$ by a factor of 3 , and overpredicts $\mathrm{CH}^{*}$ by up to a factor of 40 . If the reaction $\mathrm{C}_{2} \mathrm{H}+\mathrm{O}_{2}$ $\rightarrow \mathrm{CH}^{*}+\mathrm{CO}_{2}$ is removed, however, good agreement is obtained.

The Abel inversions also provide height profiles of the excited state concentrations at flame center for comparison with model results. The results for $\mathrm{OH}^{*}$ and $\mathrm{CH}^{*}$ in the 3 flames are shown in the first two rows of Figure 3. Concentration scales are $10^{8}$ and $10^{7} \mathrm{~cm}^{-3}$ 
respectively, and decrease with the fuel fraction. The model curves are plotted for 3 times the $\mathrm{OH}^{*}$ predictions, $1 / 30$ the $\mathrm{CH}^{*}$ predictions, and for the $\mathrm{CH}^{*}$ formed from the $\mathrm{O}+\mathrm{C}_{2} \mathrm{H}$ reaction only.

The zero height location of the profiles derived from the images is uncertain. Repeat runs can differ by 0.05 $\mathrm{cm}$, and the average peak position is unexpectedly 0.1 $\mathrm{cm}$ above the model prediction. Previous agreement of the model with $\mathrm{CH}(\mathrm{X})$ LIF peak positions, ${ }^{17}$ the $\mathrm{OH}(\mathrm{A})$ precursor, implies the model should predict the chemiluminescence peak positions well. Some data is available that places the peak of the $\mathrm{CH}^{*}$ emission with respect to the $\mathrm{CH}$ LIF maximum in the standard flame, ${ }^{32}$ and it gives a height of $0.60 \pm .02 \mathrm{~cm}$ for the maximum $\mathrm{CH}^{*}$ emissivity. The nominal peak of the current $\mathrm{CH}^{*}$ emission data (before inversion) is 0.72 $\mathrm{cm}$. Therefore all profiles shown in Fig. 3 have been adjusted backward by $0.12 \mathrm{~cm}$.

The last row of Fig. 3 shows the results for $\mathrm{C}_{2}{ }^{*}$ in the rich and standard flames. The comparison model results - the product of $\mathrm{C}$ and $\mathrm{CH}$ concentrations - reflect one likely production reaction.

\section{DISCUSSION}

The general order of chemiluminescence peaks in these flames, for both observation and model, is $\mathrm{OH}^{*}$ before $\mathrm{C}_{2}{ }^{*}$ and then $\mathrm{CH}^{*}$. The model widths appear slightly wider than the Abel-inverted measurements. Two model predictions are included for the $\mathrm{CH}^{*}$ results, corresponding to $\mathrm{C}_{2} \mathrm{H}+\mathrm{O}_{2}$ and $\mathrm{C}_{2} \mathrm{H}+\mathrm{O}$ production reactions. The $\mathrm{C}_{2} \mathrm{H}+\mathrm{O}$ runs provide a better fit for peak position, and amount. In general, the adjusted standard flame profiles show good agreement with the model, while the rich flame model is up to $0.08 \mathrm{~cm}$ later (higher) in the flame than the data. The lean flame OH(A) peaks later than the model, but a second experimental run showed much less disagreement.

The interference filter results, labeled $\mathrm{CH}(\mathrm{A})$, are plotted in the Lean $\mathrm{CH}^{*}$ panel along with the glass filter $370-460 \mathrm{~nm}$ profile. The tail in the broadband profile at heights into the burnt gases, as well as the larger than expected difference in peak magnitudes (mentioned earlier), indicates a significant minority of the broadband emission $(-20 \%)$ is not associated with $\mathrm{CH}^{*}$. This interpretation also improves model agreement, in this panel of Fig. 3 and for the Lean $\mathrm{CH}^{*}$ rows of Table 2 ..

The starting model predicts about 30 times too much excited $\mathrm{CH}$, and the production rate constants would need to be reduced by this fraction to obtain agreement (see Fig. 3). Analysis of the model shows that the $\mathrm{C}_{2} \mathrm{H}$ $+\mathrm{O}_{2}$ reaction is responsible for nearly all $\mathrm{CH}^{*}$ production. Even reducing this rate by 16 , as Mertens' work indicates, ${ }^{13}$ is insufficient. A second model without this reaction predicts the measured amounts. (The multiplier for this model value is $1.1 \pm 0.2$.) Here, the $\mathrm{C}_{2}+\mathrm{OH}$ reaction only contributes about $10 \%$; for this to be a significant cause of the chemiluminescence, the rate constant would need to be 10 times higher and nearly gas kinetic - an unlikely proposition. Our conclusion is to recommend the rate constant of $6.2 \times 10^{12} \mathrm{~cm}^{3} \mathrm{~mol}^{-1} \mathrm{~s}^{-1}$ for $\mathrm{O}+\mathrm{C}_{2} \mathrm{H}$ as the $\mathrm{CH}^{*}$ source, although any combination of $\mathrm{O}$ and $\mathrm{O}_{2}$ reactions with the same net rate will account for our results. Determining this division will require further experiments in flames with significantly different $\mathrm{O} / \mathrm{O}_{2}$ ratios. The rich/standard flame $\mathrm{CH}^{*}$ ratio results in Table 2 would suggest nearly equivalent participation. Note that the $O$ atom rate constant value is nearly the same as Joklik's acetylene flame number $\left(7 \times 10^{12}\right)$, and indicates a factor of 2 decline from the measured room temperature value. ${ }^{14}$

The Walsh diffusion flame results ${ }^{7,8}$ for $\mathrm{CH}^{*}$ are overpredicted by a factor of 3 by a model that uses GRI-Mech 2.11 chemistry and the chemiluminescence rate constants from Devriendt et al. ${ }^{14}$ Although there are enough other modeling uncertainties that one cannot derive precise values from this data, it would suggest an $\mathrm{O}+\mathrm{C}_{2} \mathrm{H}$ rate constant of $3.6 \times 10^{12}$, only $40 \%$ below our recommendation.

The results for $\mathrm{OH}^{*}$, a multiplier of $2.9 \pm 0.3$, suggest a faster rate constant for $\mathrm{CH}+\mathrm{O}_{2}$ by a factor of 3, to 1.8 $\times 10^{11} \mathrm{~cm}^{3} / \mathrm{mole} / \mathrm{s}$. Uncertainties are at least $35 \%$, and the $\mathrm{OH}^{*}$ result depends on the relative gain of the $\mathrm{CCD}$ camera in the ultraviolet (currently taken from the manufacturer's specifications). Modeling of the Walsh et al diffusion flame $\mathrm{OH}^{*}$ observations ${ }^{7.8}$ using GRIMech 2.11 and the same $\mathrm{OH}^{*}$ mechanism implies a multiplier of 1.6; the predicted position of the chemiluminescence is poor, however. The starting mechanism rate constant is from Porter' $\mathrm{s}^{15}$ analysis of 18 torr methane and acetylene flames; it depends on the ratio $\mathrm{k}_{\mathrm{Q}}[\mathrm{M}]\left[\mathrm{OH}^{*}\right] /[\mathrm{CH}]\left[\mathrm{O}_{2}\right]$, where $\mathrm{k}_{\mathrm{Q}}$ is the ratc constant for quenching by $\mathrm{M},\left[\mathrm{O}_{2}\right]$ is determined by mass spectrometric sampling, and $\left[\mathrm{OH}^{*}\right]$ and $[\mathrm{CH}]$ come from emission intensity and absorption measurements and respectively depend inversely on the transition probabilities. So $\mathrm{k} \propto \mathrm{k}_{\mathrm{Q}} /\left[\mathrm{O}_{2}\right] \mathrm{F}(\mathrm{CH}) \mathrm{F}(\mathrm{OH})$. The Porter analysis assumed an average quenching cross section of $7 \AA^{2}$, while our estimates with more recent quenching kinetics ${ }^{9}$ range from $3.5 \AA^{2}$ for the 
acetylene flames to $9.0 \AA^{2}$ for methane flames similar to our own. ${ }^{9}$ Grebe and Homann " determined a $298 \mathrm{~K}$ rate constant of $4.8 \times 10^{10}$ in an $\mathrm{H} / \mathrm{O} / \mathrm{C}_{2} \mathrm{H}_{2}$ low pressure flow system, only $20 \%$ below Porter et al. ${ }^{13}$

The $\mathrm{OH}^{*}$ concentrations and production rate constant depend on the camera intensifier gain relative to $\mathrm{CH}^{*}$. A direct calibration will refine the current preliminary values. The height profiles of Fig. 3 are also uncertain. Point measurements of emissivities and LIF as the burner height is scanned will provide greater accuracy.

Future experiments in other low pressure flames, including $\mathrm{C}_{2} \mathrm{H}_{\mathrm{x}}$ fuels, will refine these rate constant values. Flames with $\mathrm{N}_{2} \mathrm{O}$ oxidizer and hydrogen flames seeded with hydrocarbons will provide the varied $\mathrm{O} / \mathrm{O}_{2}$ ratios needed to decipher the production reaction(s) for $\mathrm{CH}^{*}$, Experiments with $\mathrm{C}-2$ and $\mathrm{C}-3$ fuels will extend the applicability of quantitative chemiluminescence diagnostics to higher hydrocarbon flames.

LIF quenching measurements of $C_{2}(d-a)$ in low pressure flames will provide the decay information needed in the mechanism to deduce excited state $C_{2}$ production rate parameters from the emission data. In addition, $C_{2}(a)$ populations can also be determined to provide a test of the kinetics mechanism involving precursors to $\mathrm{CH}^{*}$.

\section{CONCLUSIONS}

Absolute excited state concentration profiles for $\mathrm{OH}(\mathrm{A}), \mathrm{CH}(\mathrm{A}$ and $\mathrm{B})$, and $\mathrm{C}_{2}$ (d) were determined from optical emission intensities for low pressure methaneair flames of different stoichiometries. Production rate constants were then obtained from computer modeling of the flames using known excited state quenching rates. Stoichiometry variation is well predicted. The reactions and preliminary rate constants are:

$\mathrm{CH}+\mathrm{O}_{2} \rightarrow \mathrm{OH}^{*}+\mathrm{CO} \mathrm{k}=1.8 \times 10^{11} \mathrm{~cm}^{3} / \mathrm{mole} / \mathrm{s}$; $\mathrm{O}+\mathrm{C}_{2} \mathrm{H} \rightarrow \mathrm{CH}^{*}+\mathrm{CO} \mathrm{k}=6.2 \times 10^{12} \mathrm{~cm}^{3} / \mathrm{mole} / \mathrm{s}$.

The results do not, however, rule out the $\mathrm{C}_{2} \mathrm{H}+\mathrm{O}_{2}$ reaction as an alternative source of $\mathrm{CH}^{*}$. These rate parameters can be used in modeling chemiluminescence measurements in methane flames to derive quantitative chemical information from experiments.

\section{ACKNOWLEDGEMENTS}

This work was supported by the NASA Microgravity Program, contract NAS3-99143. We thank Marshall Long for supplying the Yale Abel inversion code.

\section{REFERENCES}

1. A. Eckbreth, "Laser Daignostics for Combustion Temperature and Species," Abacus Press, Cambridge MA, 1988.

2. K. Kohse-Höinghaus, Prog. Energy Combust. Sci. 20: 203-279 (1994).

3. A. G. Gaydon, "The Spectroscopy of Flames," 2nd ed., John Wiley \& Sons, New York, NY, 1974.

4. K. T. Walsh, J. Fielding, M. D. Smooke, and M. B. Long, "Experimental and Computational Study of Temperature, Species, and Soot in Buoyant and Non-buoyant Coflow Laminar Diffusion Flames," Proc. Combust. Inst.. 28, in press (2000).

5. J. Kojima, Y. Ikeda, and T. Nakajima, "Spatially Resolved Measurement of $\mathrm{OH}^{*}, \mathrm{CH}^{*}$ and $\mathrm{C}^{*}$ Chemiluminescence in the Reaction Zone of Laminar Premixed Methane/Air Flames," Proc. Combust. Inst.. 28, in press (2000).

6. H. N. Najm, P. H. Paul, C. J. Mueller, and P. S. Wyckoff, Combust. Flame 113: 312-332 (1998).

7. K. T. Walsh, M. B. Long, M. A. Tanoff, and M. D. Smooke, Proc. Combust. Inst.. 27: 615-623 (1998).

8. J. Luque, J. B. Jeffries, G. P. Smith, D. R. Crosley, K. T. Walsh, M. B. Long, and M. D. Smooke, Combust. Flame 122: 172-175 (2000).

9. M. Tamura, P. A. Berg, J. E. Harrington, J. Luque, J. B. Jeffries, G. P. Smith, and D. R. Crosley, Combust. Flame 114: 502-514 (1998).

10. R. G. Joklik, J. W. Daily, W. J. Pitz, Proc. Combust. Inst.. 21: 895-904 (1986).

11. J. Grebe, and K. Homann, Ber. Bunsenges. Phys. Chem.. 86: 581-586; ibid. 587-596 (1982).

12. S. Hwang, W. C. Gardiner, M. Frenklach, and D. Hidaka, Combust. Flame 67: 65-76 (1987).

13. J. D. Mertens, "A Shock Tube Study of $\mathrm{CH}^{*}$ Reaction Kinetics in $\mathrm{CH} 4$ and $\mathrm{C} 2 \mathrm{H} 2$ Oxidation," $22^{\text {nd }}$ Intl. Symp. On Shock Waves, Paper 4510, London, 1999.

14. K. H. Devriendt, H. VanLook, B. Ceursters, and J. Peeters, Chem. Phys. Lett. 261: 450-456 (1996). 
15. R. P. Porter, A. H. Clark, W. E. Kaskan, and W. E. Browne, Proc. Combust. Inst.. 11: $907-917$ (1966).

16. E. M. Bulewicz, P. L. Padley, and R. E. Smith, Proc. Roy. Soc. (London) A315: $129-146$ (1970).

17. P. A. Berg, D. A. Hill, A. R. Noble, G. P. Smith, J. B. Jeffries, and D. R. Crosley, Combust. Flame 121: 223-235 (2000); P. A. Berg, G. P. Smith, J. B. Jeffries, and D. R. Crosley, Proc. Combust. Inst. 27: $1377-1384$ (1998); E. W.-G. Diau, G. P. Smith, J. B. Jeffries, and D. R. Crosley, Proc. Combust. Inst.. 27: 453-460 (1998).

18. G. P. Smith, D. M. Golden, M. Frenklach, M., N. W. Moriarty, B. Eiteneer, M. Goldenberg, C. T. Bowman, R. K. Hanson, S. Song, W. C. Gardiner, V. Lissianski, and Z. Qin, GRI-Mech 3.0 Web site, http://www.me.berkeley.edu/gri_mech/, 1999.

19. J. Luque and D. R. Crosley, Appl. Phys. B 63: 9198 (1996).

20. R. J. Kee, J. F. Grcar, M. D. Smooke, and J. A. Miller, A Fortran Program for Modeling Steady Laminar One-Dimensional Premixed Flames, Sandia Report SAND85-8240, 1985.

21. S. L. Baughcum and R. C. Oldenborg, A. C. S. Symp. 249: 257-266 (1984).

22. W. E. Kaskan, J. Chem. Phys.. 31: 944-956 (1959); M. G. Davis, W. K. McGregor, and A. A. Mason, J. Chem. Phys. 61: 1352-1356 (1974).

23. K. H. Becker, H. H. Brenig, and T. Tatarczyk, Chem. Phys. Lett. 71: 242-245 (1980).

24. W. L. Dimpfl, and J. L. Kinsey, J. Quant. Spectrosc. Radiat. Transfer 21: 233-241 (1979).

25. J. B. Jeffries, K. Kohse-Höinghaus, G. P. Smith, R. A. Copeland, and D. R. Crosley, Chem. Phys. Lett. 152: $160-166$ (1988).

26. J. Luque, W. Juchmann, and J. B. Jeffries, J. Appl. Phys. 82: 2072-2081 (1997); C. Naulin, M. Costes, and G. Dorthe, Chem. Phys. Lett. 143: 496-500 (1988).

27. R. E. Ferguson, J. Chem. Phys. 23: 2085-2089 (1955).

28. J. Luque, W. Juchmann, E. A. Brinkman, and J. B. Jeffries, J. Vac. Sci. Technol. A 16: $397-408$ (1998); J. Luque, W. Juchmann, and J. B. Jeffries, Appl. Opt. 36: 3261-3270 (1997).
29. R. Gredel, E. F. vanDishoeck, and J. H. Black, Astrophys. J. 338: 1047-1070 (1989).

30. C. J. Dasch, Appl. Opt.. 31: 1146-1152 (1994).

31. J. Luque, J. B. Jeffries, G. P. Smith, D. R. Crosley, and J. J. Scherer, "Coincident Cavity Ringdown Absorption and LIF Imaging Measurements of $\mathrm{CN}(\mathrm{B}-\mathrm{X})$ and $\mathrm{CH}(\mathrm{B}-\mathrm{X})$ in Low Pressure $\mathrm{CH}_{4}-\mathrm{O}_{2}$ $\mathrm{N}_{2}$ and $\mathrm{CH}_{4}-\mathrm{NO}-\mathrm{O}_{2}-\mathrm{N}_{2}$ Flames," Combust. Flame, submitted, 2000.

32. J. Luque, P. A. Berg, J. B. Jeffries, D. R. Crosley, and J. J. Scherer, "Cavity Ringdown Absorption of $\mathrm{CH}(\mathrm{A}-\mathrm{X})$ in Low Pressure Flames," manuscript in preparation, 2000. 


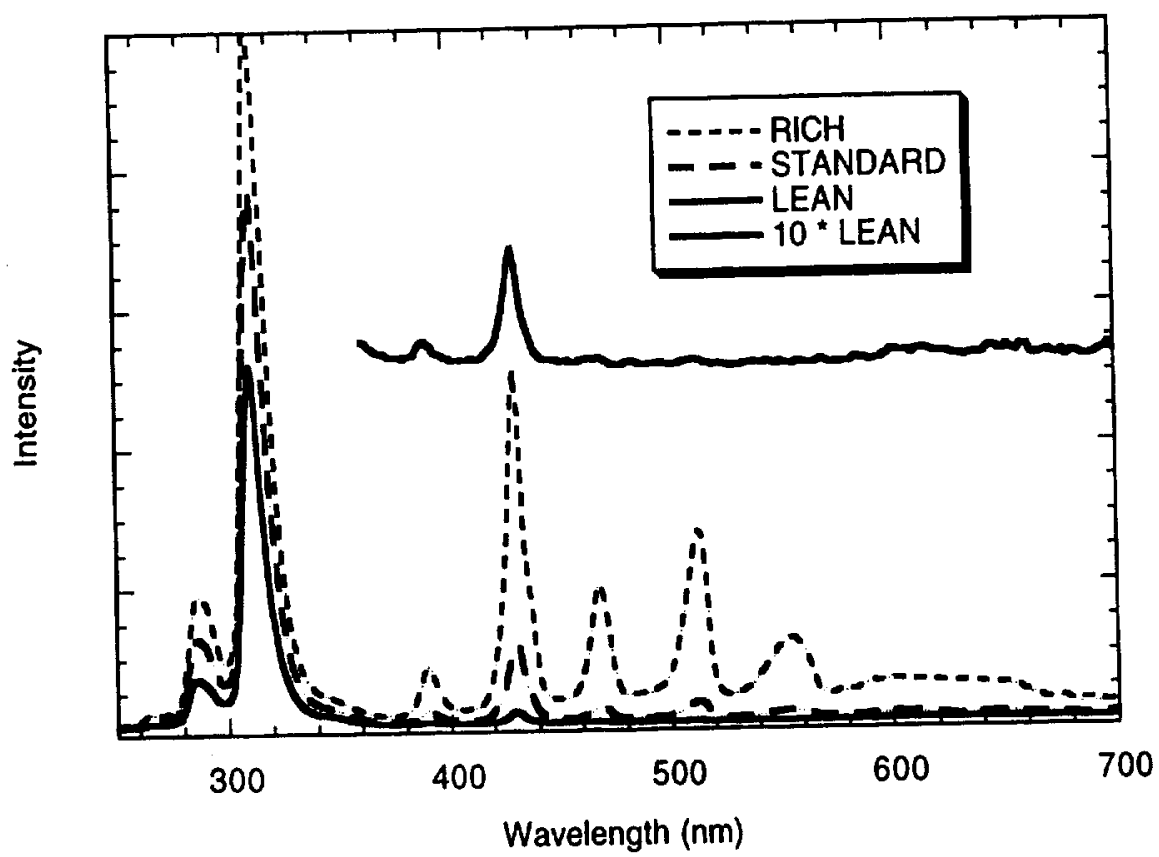

Figure 1. Flame emission spectra from the center of the three low pressure premixed methane-air flames.
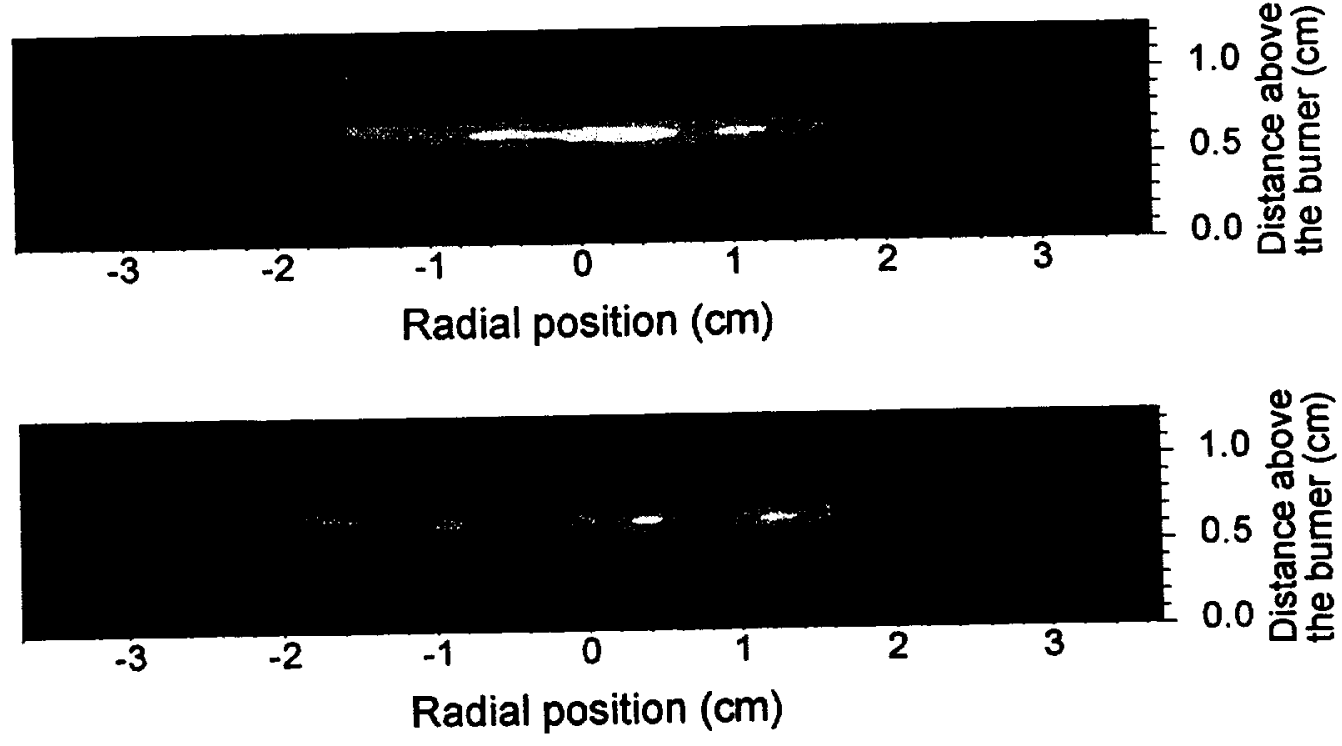

Figure 2. Bottom: 2-D Image of $\mathrm{OH}(\mathrm{A}-\mathrm{X})$ emission from the $\Phi=1.27$ methane-air 25 torr flames; Top: Abel inversion results giving the $\mathrm{OH}(\mathrm{A})$ concentration distribution through flame center as a function of radius and height. Bands show intensity contours to the light maxima at the flame center. Black background is $<10 \%$.

Figure 3. Experimental excited state profiles for $\mathrm{OH}(\mathrm{A}), \mathrm{CH}(\mathrm{A}, \mathrm{B})$, and $\mathrm{C}_{2}$ (d) (top to bottom) at the center of three low pressure methane-air flames of $\Phi=1.27,1.07$, and 0.81 (left to right). Four modified modeling results as described in the text are shown for comparison. The experimental profiles have been shifted $0.12 \mathrm{~cm}$ closer to the nominal burner surface (see text). 

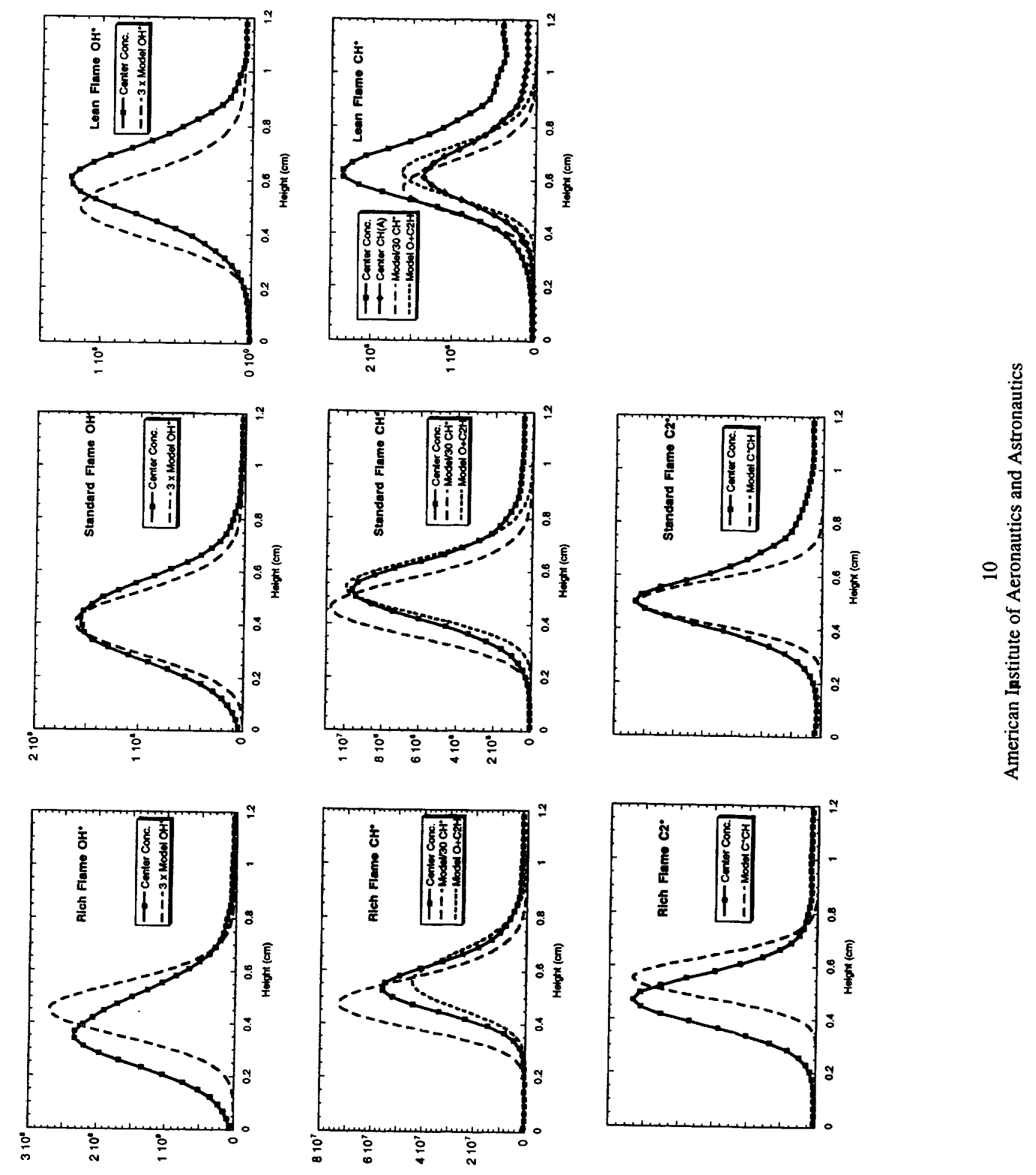